\title{
Influence of Eco-Friendly Control Strategies on the Germination of Mycotoxin Secreted Fusarium Verticillioides Infested Maize
}

\section{1*AKINBODE, OA; ${ }^{1}$ KAREEM, KT; ${ }^{1}$ ODUWAYE, OF ; ${ }^{2}$ OBAFEMI, AI}

\author{
Institute of Agricultural Research and Training (IAR\&T), Obafemi Awolowo University, Moor Plantation, Ibadan, Nigeria. \\ ${ }^{2}$ Federal University of Agriculture, Abeokuta (FUNAAB), Nigeria. \\ *Corresponding Author Email: foyedeji@yahoo.com
}

\begin{abstract}
Fusarium verticillioides is a major seed borne fungal pathogen of maize causing rots and seedling blight, and secretion of toxigenic compounds in grains. This study aimed at reducing the seedling blight and mycotoxin contamination level of maize caused by $F$. verticillioides with environmentally friendly antagonistic microorganisms. One gram of ground mycelia of each of the species of Trichoderma, B. subtilis and P. fluorescens was suspended in 100, 200, 300 and $400 \mathrm{ml}$ of distilled water to determine the inoculum concentrations. Maize seeds were treated with inoculum and planted at least 2 seeds per pot in replicates of 3 pots. Two grams of ground mycelial mat of the pathogen was added (at planting) per ten (10) kilogram of sterile soil. Germination percentage of these seeds was taken on the 14, 21, and 28 days after planting. Observations were on incidence and severity of the disease, from germination period till harvest. $T$. pseudokoningii at its $\mathrm{C} 3$ gave the best germination percentage, and $P$. fluorescens inoculum at $\mathrm{C} 2$ was the best for the control of the pathogen, which is comparatively effective as Benomyl against $F$. verticillioides. The use of ecofriendly control alternative like T. pseudokoningii and P.fluorescens should be used to in place Benomyl; it has no residual effect on the environment.
\end{abstract}

\section{DOI: $\underline{\text { https://dx.doi.org/10.4314/jasem.v22i10.22 }}$}

Copyright: Copyright $@ 2018$ Akinbode et al. This is an open access article distributed under the Creative Commons Attribution License (CCL), which permits unrestricted use, distribution, and reproduction in any medium, provided the original work is properly cited.

Dates: Received: 15 May 2018; Revised: 27 September 2018; Accepted 27 October 2018

Keywords: maize, mycotoxin, biocontrol agents, Fusarium spp

Maize (Zea mays $\mathrm{L}$ ) is the third most important cereal crop in the tropics (CIMMYT, 2000). It is an important grain crop in the world due to its ability to produce economic yields under the marginal production conditions of low soil fertility and management (FAO, 2005). Maize (Zea mays L.) is a food crop of economic significance and nutritional importance in human diet; animal feed, fodder crop and raw materials for industries. Demands for maize have always exceeded its supply in Nigeria, indicating the need for higher and better productivity in terms of quantity and quality (Smale et al., 2011). Maize is highly susceptible to both pests and parasites that cause pre- and postharvest losses which leads to great economic losses in Nigeria (Samuel et al., 2011). Diseases of maize associated with $F$. verticillioides include seed rot, root rot, stalk rot, kernel or ear rot, and seedling blight (Bacon and Hinton, 1992). It is an important contributor to maize seedling disease, and for the induction of leaf lesions indicative of foliar maize diseases. Fusarium disease of maize is among the destructive diseases in many areas of the country. It reduces crop yield, and its mycotoxin secretion causes food contamination, which makes its consumption poisonous to human and livestock. The control of this disease is important to reduce contamination thereby producing cleaner, safer maize seeds; to enhance higher yields and invariably increase the farmers' income. The use of environmentally friendly control strategies for the disease management is needed. These are beneficial antagonistic microorganisms isolated from maize rhizosphere to fight against the germination and seedling blight, which are $T$. harzianum, T. pseudokoningii, $P$. fluorescens and $B$. subtilis that were tested in this study to control the $F$. verticillioides infestation on maize germinability potentials.

\section{MATERIALS AND METHODS}

Sample collection and preparation: Test biocontrol organisms (Trichoderma harzianum, $T$. pseudokoningii, Pseudomonas fluorescens and Bacillus subtilis) used in this study (i.e. the antagonists) were from soil collected in maize growing areas (rhizosphere) of the Institute Agricultural Research and Training, IAR\&T and the soil samples collected were taken to Phytopathology Laboratory of the Crop Protection and Environmental Biology Department, University of Ibadan (UI) for isolation of the organisms. These were maintained on antibacterial PDA by adding $0.67 \mathrm{~g}$ of streptomycin powder to 500 $\mathrm{ml}$ of PDA medium for the fungal growth and PDA for 
bacterial growth. The mycelial mats of the antagonists were cultured on Potato Dextrose Agar (PDA), dried in an oven at $30^{\circ} \mathrm{C}$ and blended in a sterilized Gallenkamp blender set (which had been thoroughly washed and rinsed with $\mathrm{NaOCl}$ ) for 1 min. These mycelial mat powders were stored in sterilized Petri dishes and refrigerated at $4^{\circ} \mathrm{C}$ before use. One gram each of the species of Trichoderma, B. subtilis and $P$. fluorescens was suspended in 100, 200, 300 and 400ml of distilled water to determine the inoculum concentrations in each. The concentrations are $T$. harzianum $\left(\mathrm{C} 1=1.8 \times 10^{11}, \mathrm{C} 2=1.7 \times 10^{10}, \mathrm{C} 3=2.3\right.$ x $10^{9}, \mathrm{C} 4=5.3 \times 10^{8}$ spores $/ \mathrm{ml}$ respectively), $T$. pseudokoningii $\left(\mathrm{C} 1=2.7 \times 10^{10}, \mathrm{C} 2=5.3 \times 10^{8}, \mathrm{C} 3=\right.$ $7.1 \times 10^{7}, \mathrm{C} 4=1.5 \times 10^{7}$ spores $/ \mathrm{ml}$ respectively), $B$. subtilis and $P$. fluorescens $\mathrm{C} 1=1.0 \times 10^{9}, \mathrm{C} 2=1.0 \mathrm{x}$ $10^{8}, \mathrm{C} 3=1.0 \times 10^{7}, \mathrm{C} 4=1.0 \times 10^{6} \mathrm{cfu} / \mathrm{ml}$ respectively). The seeds were treated with these inoculum and planted at least 2 seeds per pot in replicates of 3 pots. Two grams of ground mycelial mat of the pathogen was added (at planting) per ten (10) kilogram of sterile soil, mixed thoroughly, to induce the infection. Seeds were also treated with benomyl (Benlate WP 50) a fungicide at a rate of $0.5 \mathrm{~g}$ a.i $/ 50 \mathrm{~g}$ of seeds using the same method.

Analysis and Statistical Evaluation: The germination percentage of these seeds was counted on the 14, 21, and 28 days after planting. Observation was carried out till harvest. The experiment was laid out in a 2 x 4 factorial in Completely Randomised Design. Data collected were subjected to descriptive statistics and analysis was done using SAS ANOVA at $p \leq 0.05$ to test for significant differences in treatment means.

\section{RESULTS AND DISCUSSION}

At 28 days after planting, C3 of T. pseudokoningii had $75 \%$ maize germination which was higher and better than the benomyl treated plants that had $73 \%$ germination (Table 1). The $\mathrm{C} 4$ of $T$. pseudokoningii had $60 \%$ germination and was weaker in germination compared with the control plants which had $72 \%$ germination of maize seeds planted in it. It was observed at 7 days after planting that the percentage germination for the control plants were $69 \%$ on the average. The control plants gave weak stands and had seedling blight which is symptomatic $F$. verticillioides infection. T. pseudokoningii at $\mathrm{C} 3$ gave the best germination percentage which was not significantly different from the $\mathrm{C} 1$. The least effective of the concentrations of $T$. pseudokoningii inoculum was $\mathrm{C} 4$ $=1.5 \times 10^{7}$ spores $/ \mathrm{ml}$. Benomyl was $60 \%$ germination of the maize seeds significantly higher than the rest of the treatments at 7 DAP, followed by $\mathrm{C} 2$ and $\mathrm{C} 1$ in efficacy. At the 21 and 28 DAP, C2 (with $72.66 \%$ and
$73.33 \%$ ) was significantly different from the benomyl treatment, with $64 \%$ (Table 1). P. fluorescens at the end of the observation, C2 $(73.33 \%)$ and benomyl $(64 \%)$ are significantly different from each other. C1, C3 and C4 were significantly better than the control which has the pathogen, $F$. verticillioides only in the soil. The performance of $P$. fluorescens at $\mathrm{C} 2$ was the highest i.e. it has the highest germination percentage in all but was not significantly different from $\mathrm{C} 1$. Statistically to summarize the effect of the antagonists' inoculum on the germination of maize seeds planted in infested soil (Table 1). In the first trial, T. harzianum's $\mathrm{C} 2$ and benomyl are not significantly different from each other, but different from the control, C1, C3 and C4. C1 of this antagonist did not act significantly different from control; control was not also different from C3. This suggests that for T. harzianum to be effective as an antagonist, nothing more than $\mathrm{C} 1$ should be used and nothing less than C3 should be used. But to have an efficient control as observed in the benomyl, $\mathrm{C} 1$ should be used. $T$. pseudokoningii at its $\mathrm{C} 3$ gave the best germination percentage which was not significantly different from the $\mathrm{C} 1$ of it. The least effective of the concentrations of $T$. pseudokoningii inoculum was C4. From this, it is certain that for efficient control, to have good germination of maize on infested soils, C3 should be used, and concentration above $\mathrm{C} 1$ should not be used. P. fluorescens inoculum at $\mathrm{C} 2$ was the best for the control of the pathogen causing seedling blight of maize seeds. C2 was as effective as benomyl in this trial against $F$. verticillioides. For the $P$. fluorescens, all the concentrations used were effective, but dilutions less than $\mathrm{C} 4$ should not be used in this kind of control, due to its insensitivity in in vivo state. B. subtilis was a weak bacterium against this pathogen in vivo. However, C3 concentration can still be used. Benomyl was the most effective control, but for its residual effect on the environment, as a control measure, the use of environmentally friendly control alternatives like T. harzianum, $P$. fluorescens and $T$. pseudokoningii should be used. The efficient control of this pathogen; to have good germination of maize on infested soils, C3 should be used, and concentrations above $\mathrm{C} 1$ should not be avoided. $P$. fluorescens inoculum at $\mathrm{C} 2$ was the best for the control of the pathogen causing seedling blight of maize seeds. $\mathrm{C} 2$ was as effective as Benomyl in this trial against $F$. verticillioides (Table 1). For the $P$. fluorescens, all the concentrations used were effective, but dilutions less than $\mathrm{C} 4$ should not be used due to its insensitivity in in vivo state. B. subtilis was a weak bacterium against this pathogen in vivo. However, C3 concentration can still be used. Benomyl was the most effective control, but for its residual effect on the environment, the use 
of environmentally friendly control alternatives like $P$.

fluorescens and T. pseudokoningii are recommended.

Table 1: The effect of the antagonists' inoculum on maize seed germination (in \%)

\begin{tabular}{|c|c|c|c|c|c|}
\hline & Treatments & T. harzianum & T. pseudokoningii & P. fluorescens & B. subtilis \\
\hline $1^{\mathrm{st}}$ & $\mathrm{C} 1$ & & & & \\
\hline \multirow[t]{8}{*}{ Trial } & & $75.00 \mathrm{~b}$ & 74.00ab & 63.33ab & $60.33 c$ \\
\hline & $\mathrm{C} 2$ & $84.00 \mathrm{a}$ & $70.00 \mathrm{~d}$ & $80.00 \mathrm{a}$ & $72.33 b$ \\
\hline & $\mathrm{C} 3$ & $69.00 \mathrm{~cd}$ & $75.00 \mathrm{a}$ & $65.00 \mathrm{ab}$ & $60.00 \mathrm{c}$ \\
\hline & $\mathrm{C} 4$ & $64.00 \mathrm{~d}$ & $60.00 \mathrm{e}$ & $59.33 \mathrm{ab}$ & $54.33 d$ \\
\hline & Benomyl & $86.00 \mathrm{a}$ & $73.00 \mathrm{bc}$ & $86.00 \mathrm{a}$ & $86.00 \mathrm{a}$ \\
\hline & Control & $70.66 \mathrm{bc}$ & $72.00 \mathrm{c}$ & $50.67 \mathrm{~b}$ & $70.66 \mathrm{~b}$ \\
\hline & Mean & 74.77 & 70.66 & 67.38 & 67.26 \\
\hline & S.E & 5.825 & 1.452 & 27.512 & 5.451 \\
\hline $2^{\text {nd }}$ & $\mathrm{C} 1$ & & & & \\
\hline \multirow[t]{8}{*}{ Trial } & & $63.66 \mathrm{a}$ & $75.00 \mathrm{~b}$ & $65.00 \mathrm{~b}$ & $58.66 \mathrm{~b}$ \\
\hline & $\mathrm{C} 2$ & $65.00 \mathrm{a}$ & $75.00 \mathrm{~b}$ & $73.33 \mathrm{a}$ & $64.66 \mathrm{a}$ \\
\hline & $\mathrm{C} 3$ & $58.00 \mathrm{~b}$ & $80.00 \mathrm{a}$ & $61.33 \mathrm{~cd}$ & $54.66 \mathrm{bc}$ \\
\hline & $\mathrm{C} 4$ & $48.00 \mathrm{c}$ & $60.00 \mathrm{e}$ & $59.33 d$ & $52.33 \mathrm{c}$ \\
\hline & Benomyl & $64.00 \mathrm{a}$ & $73.00 \mathrm{c}$ & $64.00 \mathrm{bc}$ & $64.00 \mathrm{a}$ \\
\hline & Control & $40.00 \mathrm{~d}$ & $72.00 \mathrm{~d}$ & $40.00 \mathrm{e}$ & $40.00 \mathrm{~d}$ \\
\hline & Mean & 56.44 & 72.50 & 60.49 & 55.71 \\
\hline & S. E & 2.334 & 0.726 & 2.994 & 5.303 \\
\hline
\end{tabular}

$\mathrm{C} 1, \mathrm{C} 2, \mathrm{C} 3$ and $\mathrm{C} 4$ are based on individual concentrations. Means of 3 replicates (\%). Means in the same column followed by the same letter are not significantly different at 0.05 level. Infected seedlings are usually stunted, wilting, chlorotic, and have pale green or purple leaves and poor roots (CIMMYT, 2004). Symptoms of Fusarium stalk rot in mature plants are difficult to distinguish from those of other stalk rots, but the internal tissues of affected stalks are usually reddish-brown and rotted. The discolouration may also be seen on the surface of the stalks near nodes. Stalks are weak and lodge easily. T. pseudokoningii had highest effect on maize germination, followed by $P$. fluorescens, and the least $B$. subtilis. Several researchers have reported that an application of fluorescent Pseudomonas to seed (Callan et al., 1990), soil and foliage (Praveen et al., 2000) also controlled several plant diseases. Lower disease incidence and resultant yield increase in seeds treated with microbial agents might be attributed to rapid multiplication of antagonists in the soil and its colonisation in the roots of seedlings, thereby preventing the establishment of the pathogens in the rhizosphere. Its effect on the phylloplane was also observed cause of its ability to control the foliar diseases. The present results revealed that $P$. fluorescens significantly controlled ear rot disease and also improved field emergence and grain yield in maize grains. Possibly both rhizosphere (to help the root systems) and phyllosphere populations of $P$. fluorescens helped to control disease. Both direct inhibition of the pathogen to systemically induced resistance in maize plants could be involved in control. Similar observations were also made on rice plants (Albouvette et al., 1993) in the case of $P$. fluorescens.
Increase in yield owing to $P$. fluorescens has been reported in several crops (Niranjan et al., 2004; Srinivas et al., 2005). The activities of species of Trichoderma showed good action in the control of the incidence of Fusarium ear rot disease on the field. The incidence of $F$. verticillioides was drastically reduced with the Trichoderma species compared to the untreated control. The action and ability of Trichoderma to act as mycoparasites of hyphae and resting structures of plant pathogens have been demonstrated both in in vitro and natural soil (Akinbode and Ikotun, 2011).

Trichoderma species are good sources of various enzymes such as exo- and endo-glucanases, cellobiase, chitinase and growth stimulators (Mari Aidemark et al., 2010). This proven ability of species of Trichoderma to produce diffusible substances toxic to other fungi in vitro and even in organic substrates in soil (Mohiddin et al., 2010), strengthens and suggests the importance of the native Trichoderma in biocontrol. Other workers have found that there are great variabilities between the different strains of Trichoderma in their ability to colonize their rhizosphere. It was observed that there was an increase in susceptibility of the plants to the disease probably due to the absence of the organism in the maize plant phyllosphere; this brought the idea of spraying with the bioagents at 6 weeks after planting.

Conclusions: To control F. verticillioides, bioagents were isolated from maize rhizosphere; $T$. harzianum, T. pseudokoningii, P. fluorescens and B. subtilis that were used in this study. The severity of Fusarium ear rot disease of maize was greatly reduced by $T$. 
pseudokoningii and P.fluorescens which can serve as a good alternative to the synthetic fungicide, benomyl used. Environmentally friendly control strategies with the use of these two bioagents is possible to reduce contamination thereby producing cleaner, safer maize seeds; to enhance higher yields and invariably increase the farmers' income. The potentials of these bioagents used in the experiment as mycoparasites of hyphae and resting structures of plant pathogens have been demonstrated both in in vitro and natural soil. The safe use of the organisms to control the Fumonisin secreting $F$. verticillioides in maize is important and should be encouraged for safer maize production.

\section{REFERENCES}

Alabouvette, C; Lemanceau, P; Steinberg C (1993). Recent advances in the biological control of Fusarium wilts. Pesticide Science 37:365-373.

Akinbode, OA; Ikotun, T (2011). Potentials of two Trichoderma species as antagonistic agents against Colletotrichum destructivum of cowpea. African Journal of Microbiology Research 5(5): 551-554, 4 March, 2011 ISSN 1996-0808 @ 2011 Academic Journals

Bacon, CW; Hinton, DM (1992). Symptomless endophytic colonization of maize by Fusarium moniliforme. Canadian Journal of Botany.74:1195-1202.

Callan, NW; Mathre, DE; Miller, JB (1990). Biopriming seed treatment for biological control of Pythium ultimum pre-emergence damping-off in Sh2 sweet corn. Plant Disease 74:368-372.

CIMMYT (International Maize and Wheat Improvement Center) (2000). CGIAR Research, Areas of Research: Maize (Zea mays L.). $<$ http://www.cgiar.org/areas/maize.htm>.

CIMMYT (International Maize and Wheat Improvement Center) (2004). Maize disease. A guide for identification. $4^{\text {th }}$ edition, Mexico D.F.124pp.

FAO (2005). Food and Agricultural Organization of the United Nations. Major food and Agricultural commodities and Producers- Comm. The Statistics Division, Economic and social Department. Pg. 1.5 of 1 .

Gnanamanickam, SS; Mew, TW (1992) Biological control of blast disease of rice (Oryza sativa L.) with antagonistic bacteria and its mediation by a Pseudomonas antibiotic. American Phytopathology Society 58:380-385.

Mari Aidemark; Henrik Tjellström; Anna S Sandelius; Henrik Stålbrand; Erik Andreasson; Allan G Rasmusson; and Susanne Widell (2010). Trichoderma viride cellulase induces resistance to the antibiotic pore-forming peptide alamethicin associated with changes in the plasma membrane lipid composition of tobacco BY-2 cells. BMC Plant Biology 10:274 doi:10.1186/1471-2229-10$274 \quad$ http://www.biomedcentral.com/1471$\underline{2229 / 10 / 274}$

Mohiddin, MR; Khan, SM; Bhat, BH (2010). Why Trichoderma is Considered Super Hero (Super Fungus) Against the Evil Parasites? Plant Pathology Journal 9: 92-102.

Praveen KL; Niranjana, SR; Prakash, HS; and Shetty, HS (2000). Effect of Pseudomonas fluorescens formulation against Pyricularia grisea in Rice. Crop Improvement 27:159-166

Samuel, A; Saburi, A; Usanga, OE; Ikotun, I; Isong, IU (2011). Post-harvest food losses reduction in maize production in Nigeria. African Journal of Agricultural Research 6 (21): 4833-4839, 5 October, 2011.

Smale, M; Byerlee, D; Jayne, T (2011). Maize Revolutions in Sub-Sahara Africa. Policy research working paper 5659. The World Bank, Development research Group, Agriculture and rural Development Team May 2011.

Srinivas, C; Niranjana, SR; and Shetty, HS (2005). Effect of bioagents and fungicides against Phomopsis vexans and on seed quality of Brinjal. J. Crop Improvement 32:95-101. 